\title{
Freight corridor performance measurement system: A framework for South Africa
}

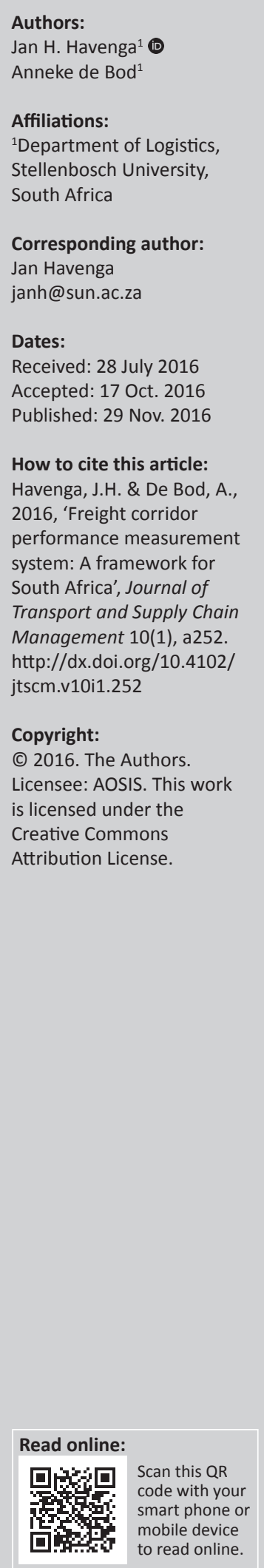

Background: On a national level, South Africa's freight logistics industry is inefficient. The country ranks 36th out of 40 countries in terms of transport productivity (tonne kilometres as a ratio of gross domestic product, or GDP); the ratio of freight logistics costs to GDP measured $11.1 \%$ in 2013 , compared to that of developed regions which measures in the order of $9 \%$; and rail tonne-km market share on the two most dense long-distance corridors, namely, GautengDurban and Gauteng-Cape Town, is only $12.8 \%$ and $4.4 \%$, respectively, whereas rail is globally acknowledged as a more efficient provider of long-distance freight solutions, given appropriate investments and service commitments.

Objectives: A cornerstone of improved national freight logistics performance is the availability of reliable indicators to quantify the efficiency and capacity of the logistics network over the intermediate and long term, thereby enabling an evidence-based policy and investment environment. The objective of this article is to describe the foundation framework (i.e. phase 1) for South Africa's freight corridor performance measurement system (CPMS). Once populated, the CPMS will be a key generator of indicators to facilitate the systemic management of corridors as a national production factor and thereby contributing to South Africa's competitiveness.

Method: The design of South Africa's CPMS was informed by desktop research and refined through an extensive stakeholder consultation process. A distinction was made between South Africa's dedicated bulk corridors and the multi-modal corridors.

Results: Facilitating both stakeholder involvement and agreement on key indicators, as well as the eventual development of a system supporting the population, aggregation and dissemination of the CPMS are critical outcomes for the management of corridors as a national production factor. Three overarching corridor indicators were defined, relating to increased throughput, lower costs and optimal modal application - the key rationale to improve the competitiveness of South African industry. This is supported by three corridor measurement perspectives, that is, a policy, customer service and infrastructure perspective. The purpose of the policy perspective is to support the role of national government in facilitating logistics competitiveness and equitable access through appropriate policy instruments. The customer service perspective should track service reliability and efficiency as contracted, at costs and cycle times that facilitate the competitiveness of the freight owner. The infrastructure perspective indicates whether sufficient capacity is provided, and whether this capacity is both available when required and utilised optimally.

Conclusion: Elevation of logistics to the macroeconomic realm through the development of appropriate indicators will enable the management of logistics as a national production factor, thereby contributing to reducing national freight logistics costs and improving industry competitiveness.

\section{Introduction}

Freight logistics performance is a strong determinant of country-level competitive advantage. Improved logistics efficiency is associated with trade expansion, export diversification, investment in productive capacity, economic growth and poverty reduction (Brunner 2013). Countries with a low score on the Logistics Performance Index (LPI) typically experience higher corridor logistics costs because of the low economies of scale for multi-modal infrastructure or structural imbalances of volumes of trade along corridors (Arvis et al. 2008). In 2016, South Africa ranked 20th out of 160 countries on the LPI (World Bank 2016). In a global comparison of transport productivity

Note: This article is partially based on the author's Dissertation of the degree of Doctor of Philosophy in Logistics Management at the Department of Logistics, Stellenbosch University, South Africa, with promoter Prof. W.J. Pienaar, received December 2007, available here: $\mathrm{http}: / /$ scholar.sun.ac.za/bitstream/handle/10019.1/1175/havenga_development_2007.pdf.txt?sequence=3 
(the relationship between tonne kilometre [tonne-km] and gross domestic product [GDP]), South Africa ranks very low at 36th out of 40 countries for which this indicator could be calculated (Havenga \& Pienaar 2012a). In addition, the country's cost of logistics as a percentage of GDP is high at $11.1 \%$ in 2013 (Havenga et al. 2016), compared to North America's 8.6\% and Europe's 9.2\% in 2014 (Armstrong and Associates Inc. 2016).

South Africa's inter-metropolitan general freight flows (i.e. corridor flows) constitute $48 \%$ of freight tonne- $\mathrm{km}$, of which rail transport only approximately 23\% (Havenga et al. 2016). Total rail tonne-km market share on the two most dense corridors, namely, Gauteng-Durban (550 km point to point) and Gauteng-Cape Town (1400 km point to point), is only $12.8 \%$ and $4.4 \%$, respectively. It is one of the European Commission's 10 goals for a competitive and resourceefficient transport system to shift $30 \%$ of road freight travelling further than $300 \mathrm{~km}$ to rail or waterways (Kallas 2011), whereas Sanchez-Triana et al. (2013) describe distances beyond $500 \mathrm{~km}$ as competitive for intermodal freight solutions.

Owing to this aberrant application of modal strengths, almost $40 \%$ of South Africa's freight transport costs are attributable to diesel costs, a volatile exogenous cost driver (Havenga \& Simpson 2013). Compounding these challenges is that South Africa's freight task is expected to treble over the next 30 years, with further concentration on the long-distance corridors (Havenga \& Simpson 2014).

One of the cornerstones of improved freight logistics performance is the availability of reliable indicators to quantify the efficiency and capacity of the logistics network over the intermediate and long term, thereby enabling an evidence-based policy and investment environment (Arvis et al. 2010; Harrison et al. 2006; Martner \& Garcia 2015). A corridor performance measurement system (CPMS) is a key generator of such indicators, facilitating the systemic management of corridors as a national production factor (Arvis et al. 2010; Kunaka \& Carruthers 2014; Martner \& Garcia 2015). The purpose of this article is to describe the foundation framework of South Africa' freight CPMS. The literature review firstly provides a context for logistics performance management in a macroeconomic environment, followed by an overview of key elements to take into account during the development and implementation of a CPMS. The research approach outlines the two-pronged approach followed to develop South Africa's CPMS; the research output describes the foundation framework of the CPMS, provides a narrative of expected results and derived policy implications, and highlights key strengths and challenges influencing the development of South Africa's CPMS. This is followed by concluding remarks and identification of next steps.

\section{Literature review Context for logistics performance management in a macroeconomic environment}

Macroeconomics as a discipline informs the overall strategic management of the country's economy in terms of the contribution of holistic components, as well as the interaction between these components. This is achieved through measuring, modelling, reporting and strategising around these components, as well as the whole, normally aggregated as benchmarks such as gross national product (GNP) and GDP. In short '[it] is the study of the behaviour of the economy as a whole' (Samuelson \& Nordhaus 1989:76). Mohr and Fourie (1996) continued by setting specific goals for the macro-economy, that is, growth, full employment, price stability, external (balance of payments) stability and fair income distribution. In order to achieve these objectives, the components or 'production factors' of the economy need to achieve optimal interaction and output, very much in the same way as in which the production factors of a firm (on the micro level) is expected to achieve optimal interaction and output. Terreblanche (1994) described economic systems as the various methods that countries (or communities) can use to organise their economic life in the broadest sense. He contended that an economic system requires economic activities that are collated according to a certain principle or principles into a coherent structure and that this structuring activity should be enforceable.

The process of economic organisation within a community is therefore total (it includes all aspects of economic life), structured (collated according to principles) and enforceable (not only spontaneous, but by a specified power). The resulting macro-organisation's existence is qualified by certain objectives (e.g. increased output, high employment and stable prices), and this qualification is achieved by certain instruments that involve trade-offs or choices (Samuelson \& Nordhaus 1989).

This process is also evident in the well-developed field of performance management on an organisational level (i.e. at a microeconomic level). Kaplan and Norton (1996) elevated this discipline with the development of the balanced scorecard, where the financial perspective is supplemented by an integrated set of measures that links customers, internal business processes and employee development to managerial and business performance. Keebler et al. (1999:34) referred to dramatic improvements that are enabled by effective performance measurement on a complete and integrated business process level, warning against a 'narrow functional focus' that can have counterproductive effects on the performance of the supply chain as a whole.

Kaplan and Norton (1996) also related the balanced scorecard back to strategy and the fundamental question of identifying the core business and the rationale for its existence, an iconic question first posed by Theodore Levitt nearly 50 years ago (Levitt 1960). Cobbold and Lawrie (2002:2) maintained that 'for control to be effective, it needs to be informed about both the activities and results delivered by the organisation, and the organisation's prior expectations concerning both'. Morgan (2004) also urged managers to understand the big picture while guarding against generic solutions to 
business challenges. To relate performance measurement to objectives seems axiomatic but, in the context of logistics as a macroeconomic production factor, it has not yet become an accepted practice.

Demkes and Tavasszy (2000:15-16) discussed the difference between macro- and micro-level indicators in-depth and found the problem in the meso area (refer Figure 1), because:

the macro indicators focusing on welfare maximisation are mostly decomposed into meso-level indicators focusing on welfare optimisation, under the condition of subsidiarity, for sectors or regions, and not on supply chains. (pp. 15-16)

The question arises about the level of indicators that measures the objectives for an important macroeconomic system, such as a corridor. In the South African economy, 'cluster studies' were initiated by the Department of Trade and Industry to evaluate and consider the contribution, effectiveness and prospects of various economic clusters in South Africa (Hirsch 2005). Implementation of strategies resulting from these studies was challenging; the macroeconomic approaches were not necessarily geared towards microeconomic principles in economic management, pointing to a gap in what Demkes and Tavasszy (2000) labelled 'meso-level' indicators. The studies did, however, highlight, amongst others, inefficiencies within industries, as well as in relationships between industries (Hirsch 2005:154). These inter-industry relationships include the distribution of resources in the economy (i.e. logistics). A corridor, to a large extent, mimics an industrial cluster. Two decades after the realisation of the importance of a coordinated sectoral view for industrial development, there is also a recognition that a similar coordinated view is required to manage logistics as a national production factor. Given the nature of the macro freight logistics landscape discussed in the introduction, priority was given to a CPMS.

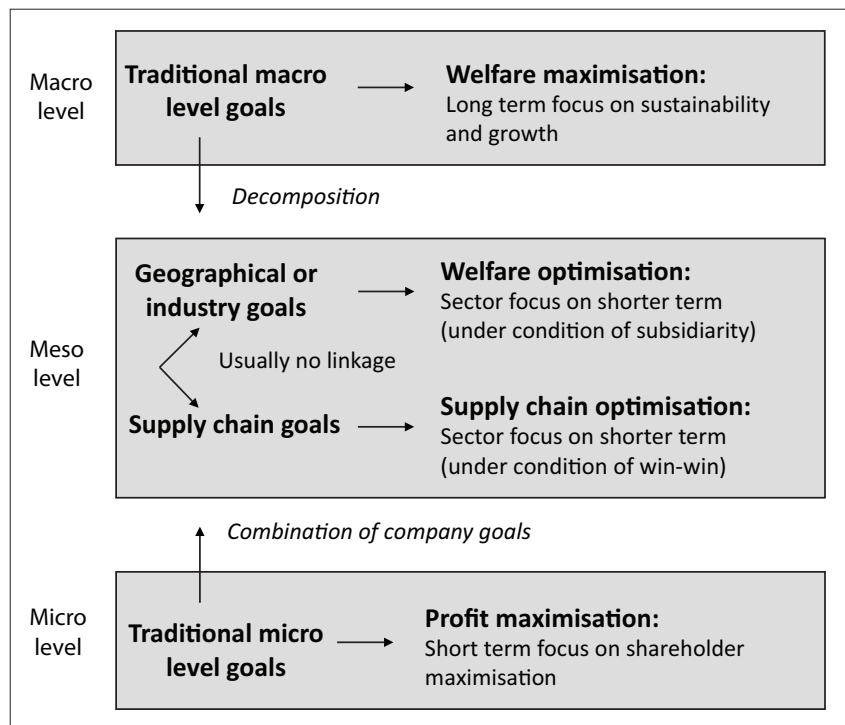

Source: Demkes, R. \& Tavasszy, L.A., 2000, 'Benchmarking infrastructure and logistics services across Europe, Asia-Pacific and North America', paper presented at IMRL 2000 Third International Meeting for research in Logistics, Trois-Rivieres, QC, 09-11 May 2000

FIGURE 1: Micro-, meso- and macro-level indicators.

\section{Key elements of corridor performance measurement system design and implementation}

\section{What is a corridor?}

A trade and transport corridor is a coordinated bundle of transport and logistics infrastructure and services that facilitates trade and transport flows between major centres of spatially separated economic activity (Kunaka \& Carruthers 2014). Corridors also play an important role in creating patterns of regional economic development and, ideally, should be managed proactively to enable inclusive growth and market access improvements (Brunner 2013). This can be influenced through the key corridor characteristics of capacity, cost and service, which determine the relative cost, speed and reliability of using an alternative corridor (Chow 2007). The expanding role of corridors from a purely transit perspective to the network effects of facilitating sustainable development through hinterland access, regional integration and the creation of industrial clusters hinges on the fundamentals of efficient logistics service offerings, which can only be determined through measurement (Hartmann 2013). The delineation of a corridor for measurement purposes presupposes the availability of a geographically disaggregated modal freight flow database (Martner \& Garcia 2015).

\section{What is a corridor performance measurement system?}

A CPMS is driven by integrated corridor management that focuses on the coordinated management of transportationand associated systems within a corridor. The objectives generally relate to a desire to increase efficiency, accessibility and mobility; improve transportation safety; accelerate information dissemination to corridor users; advance coordination amongst institutional partners; and improve network management. The resulting operational goal is to manage corridors as a single system rather than as a collection of separate systems (Dion \& Skabardonis 2015).

A CPMS presupposes an agreed measurement framework, successful measurement against this framework, and comparison to an agreed benchmark to evaluate performance. This is followed by analytics to identify root causes of challenges and develop targeted remedial interventions. Finally, the effectiveness of interventions is monitored by comparing performance over time and tracking a return to the agreed 'norm' (Hartmann 2013; Punungwe, Munyaradzi \& Simataa 2009). A CPMS has distinct benefits for key stakeholders (Hartmann 2013; Kunaka \& Carruthers 2014):

- For freight owners, corridor performance centres on competitiveness (encompassing cost, time and predictability associated with the seamless movement of freight along corridors).

- For policy-makers, the long-term balancing of supply (logistics infrastructure and services) and demand (trade volume) on the corridors and, beyond pure logistics, spatial development in order to improve national competitiveness and support socio-economic ideals. 
- For logistics service providers (LSPs), optimum use of capacity, informed capital investments and fair return on investment.

The increased situational awareness enabled by a functional CPMS will improve management practices and decisionmaking related to corridors, improving corridor performance. In addition, more optimal modal decision-making can positively impact freight-related externalities such as improved air quality, reduced congestion and reduced accidents (Dion \& Skabardonis 2015).

\section{What is measured?}

For the sake of sustainability, selected indicators should be based on consistent, relevant parameters; be readily comprehensible to and shareable with key stakeholders; be forecastable; and be easy to populate by leveraging data measured regularly by main stakeholders. The key corridor performance indicators remain the core traffic descriptors and their variance (Harrison et al. 2006; Hartmann 2013; Martner \& Garcia 2015; Punungwe et al. 2009):

- Price (cost to shipper and cost factors of LSPs).

- Time (work and idle time; physical and documentation time) and reliability.

- Volumes in tonnes and tonne-km (by corridor components and trade types).

- Infrastructure and service resilience (current and longterm capacity adequacy, utilisation and efficiency).

These indicators are measured per mode (e.g. road or rail) and per node (e.g. intermodal terminals) on the corridor. A CPMS should also strive towards combined indicators for enhanced analytical power (Punungwe et al. 2009). Canada's corridor measurement model, Fluidity, for example, is condensed into two key indicators. Firstly, the Fluidity Index that compares the average travel time in the time period of interest to travel time during free-flow conditions. Secondly, the Planning Time Index that represents total travel time that should be planned to ensure on-time delivery, comparing near-worst-case travel time to free-flow travel time. The two fluidity indicators are ratios of time, with the core focus to measure freight mobility (Eisele et al. 2011).

Punungwe et al. (2009) summarised indicators into infrastructure and quality of service perspectives, whereas Farzaneh et al. (2012) proposed measures for sustainable freight movement using the social, economic and environmental triple bottom-line framework. The frequency and granularity of performance monitoring vary according to the dimension measured, with minimal and static data for the characteristics of the infrastructure and logistics services, an intermediate level for prices and costs, and intensive needs for times and volumes (Hartmann 2013; Punungwe et al. 2009).

\section{How is it measured?}

Data can be primary indicators (such as capital expenditure on national roads), derivative or secondary indicators (based on modelling), and survey-based indicators (such as cross-border surveys) (Hartmann 2013). In most cases, all three data approaches are necessary to populate different aspects of the CPMS and obtain its full benefit. Experience in sub-Saharan Africa and the Central Asia Regional Economic Cooperation (CAREC) programme, however, highlights the challenges with data collection (Punungwe et al. 2009). Incumbents are often either reluctant to part with primary data, or legacy systems hamper accurate and timely data provision. Secondary indicator modelling is data-intensive and costly, whereas survey-based data gathering is prone to low response rates, long lead times and high costs (Liao 2014; Punungwe et al. 2009; Transport Canada 2014). Commitment for data provision from major logistics role-players, and from funding sources for modelling and surveys, is therefore probably the key determining factor of the success of the CPMS.

\section{How are measurement outcomes evaluated?}

Comparison is a natural outflow of measurement. There is, however, little agreement on reference values, because of the diversity of requirements and characteristics amongst corridors (Brunner 2013; Hartmann 2013). Consistent crosscountry comparisons are even more complex (Arvis et al. 2008). Performance indicators are therefore assessed using either relevant international or in-country benchmarks or, alternatively, using baseline indicators. A benchmark is usually obtained from ideal conditions where the movement of goods is smooth, that is, high infrastructure quality, limited regulatory bottlenecks, and efficient logistics services. The target is to move towards the benchmark. In contrast, baseline indicators reflect current conditions and therefore existing inefficiencies, low capacities, or poor quality of services, in which case the target is to move away from the baseline. Because benchmarks are difficult to set, baseline indicators are often used (Punungwe et al. 2009). Targets are also value chain specific. Shippers of bulk cargoes and low-value commodities are, for example, more concerned with minimising cost, whereas shippers of containerised and high-value goods focus on time and reliability (Hartmann 2013).

\section{Governance}

The institution to which the CPMS is anchored must have a mandate to drive or facilitate the policy dialogue, or at least have an important consultative role in that policy dialogue (Hartmann 2013). The commitments for data provision to the CPMS (e.g. content, periodicity and scope of use) should be formalised into interchange agreements. Private sector involvement and stream-lined institutional arrangements are fundamental to the success of corridor measurement systems (Ntamutumba 2010). The nature and complexity of CPMS development give rise to a specific set of implementation risks that need to be managed. These relate mainly to system development, communication and cooperation between project stakeholders, continuity in key individuals on project, funding and scheduling prioritisation given to the project by stakeholders. Understanding and managing these risks should form a core, overt part of project management and execution (Dion \& Skabardonis 2015). 


\section{Research approach}

The literature survey informed a two-pronged approach to develop South Africa's CPMS:

- Stakeholder engagement: System definition and design were accomplished through workshops with major industry associations (comprising LSPs and freight owners), state-owned infrastructure owners and operators (Transnet and the South African National Road Agency [SANRAL]), the sponsor was the Department of Public Enterprises and supporting Ministries of Trade and Industry, and Transport. This is in line with the approach followed to create the United States' Integrated Corridor Management concept (Dion \& Skabardonis 2015).

- Data sourcing: System population will be fast-tracked by sourcing primary data from Transnet (rail, port and pipeline infrastructure and freight traffic flows), SANRAL (national road infrastructure and traffic counts) and the South African Revenue Services Customs Division (crossborder data) and using secondary data from South Africa's world-class logistics costs, freight demand and national freight flow models (NFFMs). A ground-breaking input is actual container content data sourced from shipping lines, which significantly enhances commoditylevel and modal-shift modelling.

\section{Stakeholder engagement}

The complexity of the LSP industry and the plethora of freight owners involved on corridors render individual stakeholder consultations impossible. The most effective approach is to obtain buy-in and inputs through industry association engagements. Industry associations are mature, active substrata of the South African economy, playing significant intra- and inter-industry, and governmental liaison roles. The industry associations listed in Box 1 were identified as key stakeholders and participated in one or more workshops. System development was an iterative process of desktop research, workshop input and stakeholder alignment. The final sign-off was, however, the prerogative of the sponsor.

BOX 1: Industry associations involved in the corridor performance measurement system design and development.

\begin{tabular}{|c|c|c|}
\hline & $\begin{array}{l}\text { Federation of Supply Chain } \\
\text { Management Associations (FSCMA), an } \\
\text { umbrella body for Supply Chain } \\
\text { Management Organisations: } \\
\text { - The South African Association of } \\
\text { - Freight Forwarders (SAAFF). } \\
\text { The Chartered Institute of } \\
\text { Purchasing and Supply (CIPS) (over } \\
3000 \text { members in the Southern } \\
\text { African region). } \\
\text { - Council of Supply Chain Management } \\
\text { - Professionals (CSCMP). } \\
\text { The Chartered Institute of Logistics } \\
\text { and Transport South Africa (CILTSA). } \\
\text { Consumer Goods Council of South } \\
\text { Africa (CGCSA) (representing over } \\
11 \text { 000 member companies in the } \\
\text { retail, wholesale and manufacturing } \\
\text { of consumer goods). } \\
\text { - The Association of Operations } \\
\text { Management of South Africa } \\
\text { (SAPICS). } \\
\text { - South African Institute for Industrial } \\
\text { Engineers (SAllE). } \\
\text { - Supply Chain Council (SCC). } \\
\text { Road Freight Association (RFA). }\end{array}$ & $\begin{array}{ll}\text { - } & \text { National Association of } \\
\text { Automobile } \\
\text { Manufacturers of South } \\
\text { Africa (NAAMSA). } \\
\text { Shippers Council. } \\
\text { Automotive Industry } \\
\text { Development Corporation } \\
\text { (AIDC). } \\
\text { Exporters Club of South } \\
\text { - } \quad \text { Africa (ECSA). } \\
\text { Transport Forum. } \\
\text { Container Logistics } \\
\text { Operator Forum (CLOF). } \\
\text { Business Unity South } \\
\text { Africa (BUSA). } \\
\text { Rail Road Association of } \\
\text { South Africa (RRA). }\end{array}$ \\
\hline
\end{tabular}

\section{Data sourcing}

The CPMS development was facilitated by the availability of established research to quantify logistics costs and transport volumes in South Africa, refined over the past two decades. The Freight Demand Model (FDM) is a demand-side model, based on the national input-output model, estimating supply and demand of commodities in geographical areas, and translating this into modal share through gravity modelling, currently for 83 commodity groupings in 372 geographical areas with a 30-year forecast at 5-year intervals for three scenarios (Havenga 2013). Results are calibrated with industry research and correlated with known freight flows (i.e. rail, pipelines and conveyor belts). The NFFM is a supply-side model that translates vehicle counts into pre-defined long-distance and rural road freight flows (Havenga \& Pienaar 2012b). By combining the functionalities of the FDM with the NFFM, monthly bi-directional commodity flows can be estimated for road and compared to actual rail shipments in order to determine modal market share. The model will also, based on the detailed vehicle class information available from traffic counts, be able to determine target rail market share in real time, that is to identify road freight that is railfriendly.

The logistics cost model is a bottom-up aggregation of logistics-related costs for commodity-level tonnes produced and imported, comprising transport, storage and porthandling costs, management and administration costs, and inventory carrying costs (Havenga 2010). The model was recently expanded to include detailed externality cost modelling per mode pertaining to accidents, congestion, emissions, noise, policing and land-use value (Havenga 2015). De Jong et al. (2013) recognised that the inclusion of logistics modules in national and international freight transport models within Europe since 2004 has been critical to inform and evaluate policy measures.

It is important to note that although the availability of these models provide a significant leapfrog-advantage for the population of a CPMS (compared to most other countries), these models were developed to, at first, quantify South Africa's macro freight logistics landscape. As with any macroeconomic model, challenges are experienced in disaggregation, and population of the CPMS cannot purely rely on disaggregated values from the national models. Rigorous interrogation of the data with knowledgeable stakeholders, and updates as required, is imperative, both to enhance the usefulness of the outputs and to engineer continuous stakeholder buy-in through data validity.

\section{South Africa's dual freight corridor landscape}

South Africa has two distinct freight corridor systems, the nature of which dictates the development of two discrete CPMS dashboards. These are the bulk export corridors that include the two world-class ring-fenced export corridors 
(Richards Bay coal exports and Sishen-Saldanha iron ore exports) and manganese exports from the Northern Cape to Port Elizabeth, and the second system is the multi-modal, general freight corridors (refer Table 1).

The benefit of the availability of the established FDM described previously is that South Africa's multi-modal freight corridors have been defined from first principles how traffic actually behaves in the economy. This fast-tracks the development and implementation of a CPMS as corridor definition is an onerous task at the outset of a CPMS (Dion \& Skabardonis 2015). South Africa's most dense multi-modal corridors are Gauteng-Durban and Gauteng-Cape Town (refer Figure 2).

TABLE 1: Description of South Africa's two distinct freight corridor systems.

\begin{tabular}{|c|c|c|}
\hline Characteristic & Bulk export corridors & $\begin{array}{l}\text { Multi-modal, general } \\
\text { freight corridors }\end{array}$ \\
\hline \multirow{2}{*}{$\begin{array}{l}\text { Origin-destination (OD) } \\
\text { pairs }\end{array}$} & One-directional & Bi-directional \\
\hline & $\begin{array}{l}\text { Few origins and single } \\
\text { destination }\end{array}$ & $\begin{array}{l}\text { Multiple origins, multiple } \\
\text { destinations and limited } \\
\text { long-distance ODs }\end{array}$ \\
\hline Modal competition & Rail-only & Multi-modal \\
\hline Traffic type & $\begin{array}{l}\text { Single commodity, } \\
\text { low-value, bulk export } \\
\text { coal and iron ore }\end{array}$ & $\begin{array}{l}\text { Multiple commodities } \\
\text { (mostly manufacturing; } \\
\text { some agriculture), higher } \\
\text { value and increased time } \\
\text { sensitivity }\end{array}$ \\
\hline \multirow[t]{2}{*}{ Supply chain structure } & Mines, ports and rail & $\begin{array}{l}\text { Various industries, channels } \\
\text { and logistics service } \\
\text { providers involved, } \\
\text { consolidation and } \\
\text { deconsolidation of } \\
\text { commodities }\end{array}$ \\
\hline & $\begin{array}{l}\text { Limited individual supply } \\
\text { chains }\end{array}$ & $\begin{array}{l}\text { Myriad supply chains tied } \\
\text { together }\end{array}$ \\
\hline Major challenge & Global competitiveness & $\begin{array}{l}\text { Spatial organisation and } \\
\text { efficiency }\end{array}$ \\
\hline Ideal logistics approach & $\begin{array}{l}\text { Ring-fenced, bulk rail } \\
\text { systems (established) }\end{array}$ & $\begin{array}{l}\text { Domestic intermodal } \\
\text { solutions (not established) }\end{array}$ \\
\hline
\end{tabular}

Source: Based on Havenga, J.H. \& Pienaar, W.J., 2012b, 'The creation and application of a national freight flow model for South Africa', Journal of the South African Institution of Civil Engineering 54(1), 2-13

\section{Research output}

Learnings from the literature survey, combined with the outputs of the stakeholder engagement process, resulted in the development of project governance principles, overarching metrics, detailed measurement perspectives and key performance areas (KPAs) for South Africa's CPMS.

\section{Project governance}

The CPMS is developed as a permanent mechanism managed under the auspices of the Department of Public Enterprises, supported by the Ministries of Transport and Trade and Industry, to monitor and address corridor performance in an intelligent, systematic and constructive manner. The following vision and objectives will steer the activities of the CPMS:

- Vision: The CPMS is a corridor performance measurement tool to unlock economic potential by facilitating the establishment of a South African logistics network that is globally competitive and characterised by optimal performance, meeting the needs of its stakeholders.

- Objectives: To establish a single corridor intelligence platform enabling informed, collaborative freight logistics infrastructure management and investment which will result in improved governance, capacity and service levels, reducing logistics cost and transit times, and enabling increased volume throughput on the network.

The guiding principles for decision-making are as follows:

- To facilitate collaborative planning between road, rail, intermodal and port infrastructure and interfaces in order to ensure that capacity to sustainably serve the country's needs is provided ahead of demand.

- To provide capacity through operational efficiencies before infrastructure provision.

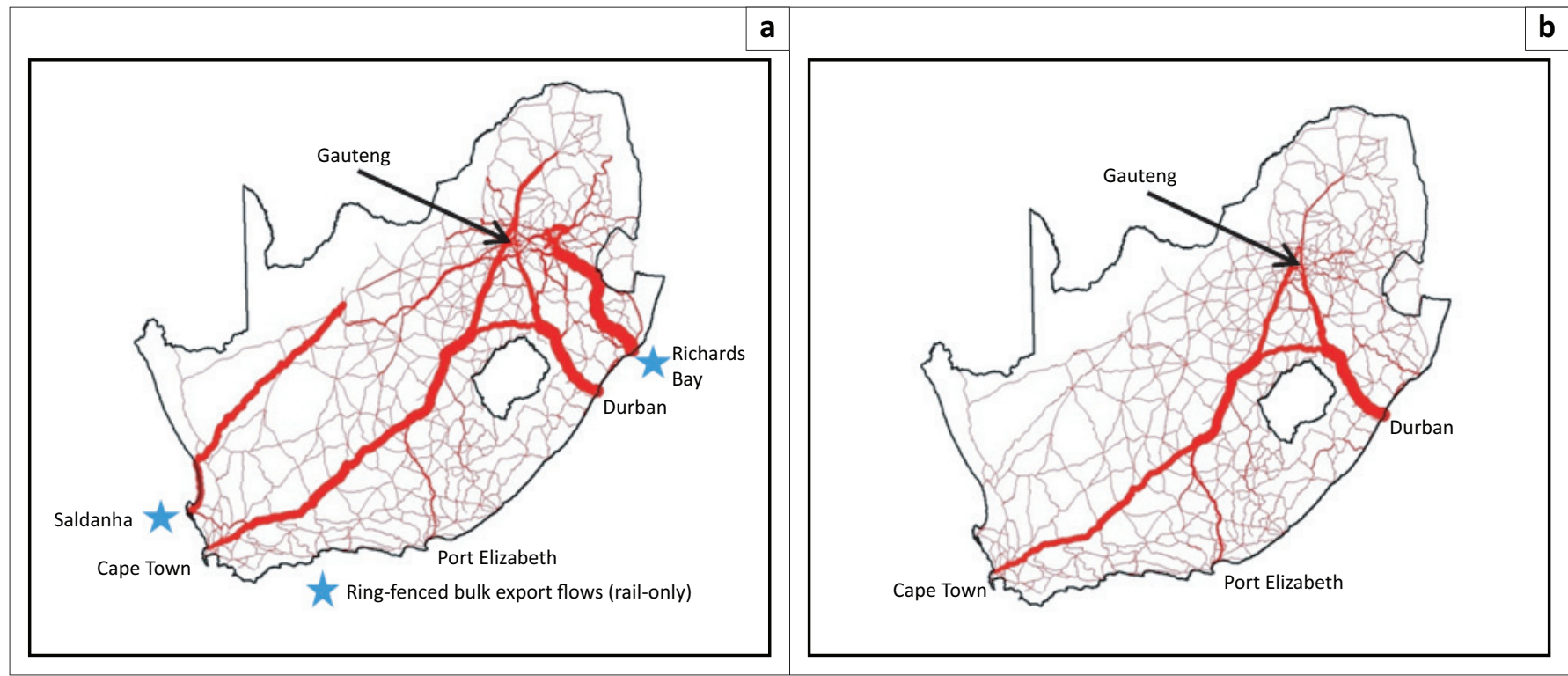

Source: Data from the model described in Havenga, J.H., 2013, 'The importance of disaggregated freight flow forecasts to inform transport infrastructure investments', Journal of Transport and Supply Chain Management 7(1), Art. \#106. http://dx.doi.org/10.4102/jtscm.v7i1.106

FIGURE 2: Geographical presentation of South Africa's freight flow density - bulk export and general freight concentrations are distinct. Flow of (a) volume and (b) value for 2013. 
- To ensure the effective utilisation of existing logistics infrastructure inter alia through an appropriate modal split between road and rail.

- To focus on hub-to-hub services to increase efficiency.

- To facilitate inclusive growth and market access improvements.

A Steering Committee (Steercom), with representatives from major industry associations (comprising LSPs and freight owners), state-owned infrastructure owners and operators (Transnet and SANRAL), the sponsor Department of Public Enterprises, and supporting Ministries of Trade and Industry, and Transport, should be established.

\section{Overarching metrics}

The purpose of the overarching metrics of the CPMS is to track aggregate corridor performance. The three metrics that have been selected in the foundation framework are as follows:

- Throughput, as measured by total road and rail volumes, moved from corridor-entry to corridor-exit. Improved total throughput will lead to improved densities and therefore lower cost, whereas a decrease in road corridor tonne-km market share points to modal optimisation, a reduction in road externalities and a reduced national exposure to the external risk of imported crude oil (the main road cost driver).

- Cost, as measured by the actual cost per tonne-km to service customers (data for road, rail and total). Reduced cost per tonne-km in the short to medium terms points to more efficient freight movements given the sizeable opportunity for intermodal solutions in South Africa. In the longer term, costs need to be managed dynamically, informed by investment and service needs.

- Optimal modal selection as measured by tonne-km per route-kilometre per mode. Improved rail density points to increased loading efficiency and economy of freight traffic movement.

These metrics can be aggregated to reflect the two macroeconomic logistics indicators proposed by Havenga (2010), namely:
- Total logistics costs as a percentage of GDP (measures the overall performance of the system).

- Road corridor tonne-km market share (measures modal optimisation and resulting exposure to external risk).

To support the data needs of the different stakeholders and facilitate analytics in support of the overarching metrics, three measurement perspectives have been identified for each of South Africa's freight corridors targeted for the CPMS, namely, a policy, customer service and infrastructure perspective (informed by Farzaneh et al. 2012; Martner \& Garcia 2015; Punungwe et al. 2009). The KPAs, metrics, rationale for inclusion and the measure of success for each metric (to be calculated per corridor) are described below for each measurement perspective for both multi-modal and bulk corridors.

\section{Measurement perspectives and key performance areas}

The four bi-directional multi-modal corridors currently included in the CPMS are as follows:

- Gauteng-Durban

- Gauteng-Cape Town

- Gauteng-Lebombo border post (the border with Mozambique)

- Gauteng-Port Elizabeth-Nqgura-East London corridor.

These corridors contribute approximately two-thirds of the countries general freight tonne-km.

South Africa only has three dedicated bulk corridors, which are all included in the first phase of the CPMS, namely:

- The iron ore export corridor from Sishen to Saldanha.

- The coal export corridor from Mpumalanga to Richards Bay.

- The manganese export corridor from the Northern Cape to Port Elizabeth.

Given the nature of the competitive dynamics on the bulk export and multi-modal corridors, the policy perspective contains different measurement elements, as described in Tables 2 and 3. Table 4 and Table 5 contain the customer

TABLE 2: Multi-modal corridors - policy perspective key performance areas.

\begin{tabular}{|c|c|c|c|}
\hline Key performance areas & Metric(s) & Rationale & Measure of success \\
\hline Road and rail market share & Tonnes (road and rail) and rail percentage share & Opportunity for modal shift & Growth in rail market share \\
\hline Road and rail transport costs & $\begin{array}{l}\text { Cents per tonne-km (road, rail and total } \\
\text { corridor) }\end{array}$ & Potential monetary return of modal shift & $\begin{array}{l}\text { Reduction in total corridor cents per } \\
\text { tonne-km }\end{array}$ \\
\hline Rail-friendly volumes currently on road & Tonnes & Ease of modal shift & Reduction in rail-friendly road volumes \\
\hline $\begin{array}{l}\text { Cost impact of optimal modal split } \\
\text { (rail-friendly volumes shift to rail) }\end{array}$ & Total monetary value & Depicts macroeconomic cost saving & $\begin{array}{l}\text { Reduction in monetary value means } \\
\text { correct modal shift is occurring }\end{array}$ \\
\hline \multirow[t]{2}{*}{ Commodity composition } & Tonnes per commodity per mode & $\begin{array}{l}\text { Identification of low-hanging fruit for modal } \\
\text { shift }\end{array}$ & Rail-friendly freight shifting to rail \\
\hline & & $\begin{array}{l}\text { Identification of export diversification and } \\
\text { beneficiation }\end{array}$ & $\begin{array}{l}\text { Increase in beneficiation closer to } \\
\text { source }\end{array}$ \\
\hline \multirow[t]{4}{*}{ Corridor capacity } & Current modal capacity vs. current modal split & \multirow{4}{*}{$\begin{array}{l}\text { Indicates the size of the capacity challenge - } \\
\text { to inform and direct critical infrastructure } \\
\text { spend and inform policy instruments }\end{array}$} & \multirow[t]{4}{*}{$\begin{array}{l}\text { Convergence of future capacity and } \\
\text { optimal road and rail split }\end{array}$} \\
\hline & Current optimal modal split & & \\
\hline & $\begin{array}{l}\text { Future modal capacity (based on investment } \\
\text { plans) }\end{array}$ & & \\
\hline & Optimal 30-year forecast modal split & & \\
\hline
\end{tabular}


TABLE 3: Bulk export corridors - policy perspective key performance areas.

\begin{tabular}{|c|c|c|c|}
\hline Key performance areas & Metric(s) & Rationale & Measure of success \\
\hline $\begin{array}{l}\text { Road and rail market share (here all road } \\
\text { share is identified as rail-friendly) }\end{array}$ & $\begin{array}{l}\text { Tonnes (road and rail) and rail } \\
\text { percentage share }\end{array}$ & $\begin{array}{l}\text { Identify issues and fast track solutions } \\
\text { to shift bulk traffic back to rail }\end{array}$ & $\begin{array}{l}100 \% \text { rail market share given rail's bulk } \\
\text { advantage }\end{array}$ \\
\hline Road and rail transport costs & $\begin{array}{l}\text { Cents per tonne-km (road, rail and } \\
\text { total corridor) }\end{array}$ & $\begin{array}{l}\text { Potential monetary return of } \\
\text { modal shift }\end{array}$ & $\begin{array}{l}\text { Reduction in transport costs for bulk } \\
\text { commodities }\end{array}$ \\
\hline $\begin{array}{l}\text { Cost impact of optimal modal split } \\
\text { (all bulk on rail) }\end{array}$ & Total monetary value & $\begin{array}{l}\text { Depicts macroeconomic } \\
\text { cost saving }\end{array}$ & $\begin{array}{l}\text { Reduction in monetary value means correct } \\
\text { modal shift is occurring }\end{array}$ \\
\hline Producer access & $\begin{array}{l}\text { Number of producers: access granted } \\
\text { versus access applied for } \\
\text { Volume per producer: access granted } \\
\text { versus access applied for }\end{array}$ & $\begin{array}{l}\text { Facilitate curtailment of cartel formation } \\
\text { Ensure access to junior miners } \\
\text { Facilitate black economic empowerment }\end{array}$ & $\begin{array}{l}\text { Move towards equitable access where all } \\
\text { applicants have an equal opportunity to gain } \\
\text { access proportional to volumes produced }\end{array}$ \\
\hline Corridor capacity & $\begin{array}{l}\text { Graphic comparison of tonnes: } \\
\text { producer's demand; rail and road } \\
\text { actuals; rail capacity; targeted } \\
\text { throughput; port capacity }\end{array}$ & Indicates size of the capacity mismatch & $\begin{array}{l}\text { Road market share approaches zero } \\
\text { Convergence of producer demand and } \\
\text { targeted throughput into one metric } \\
\text { Convergence of producer demand, rail } \\
\text { capacity and port capacity to optimise } \\
\text { production versus infrastructure } \\
\text { investment }\end{array}$ \\
\hline
\end{tabular}

TABLE 4: Bulk export and multi-modal corridors - customer perspective key performance areas.

\begin{tabular}{|c|c|c|c|}
\hline Key performance areas & Metric(s) & Rationale & Measure of success \\
\hline \multirow[t]{4}{*}{ Customer service } & On time arrivals and departures & $\begin{array}{l}\text { Reliability facilitates efficient supply chain } \\
\text { management }\end{array}$ & Growth in $\%$ on time arrivals and departures \\
\hline & \multirow[t]{2}{*}{$\begin{array}{l}\text { Volumes transported (actual compared with } \\
\text { contracted compared with customer demand) }\end{array}$} & \multirow[t]{2}{*}{$\begin{array}{l}\text { Meeting demand contributes to sustainable } \\
\text { economic growth }\end{array}$} & $\begin{array}{l}\text { Volumes transported = volumes contracted } \\
\text { (short term) }\end{array}$ \\
\hline & & & $\begin{array}{l}\text { Volumes transported = maximum demand } \\
\text { (long term) }\end{array}$ \\
\hline & Port productivity in tonnes per hour & $\begin{array}{l}\text { Benchmark productivity reduces costs } \\
\text { (congestion, delays) and increases throughput }\end{array}$ & $\begin{array}{l}\text { Tonnes per hour approaches international } \\
\text { benchmarks }\end{array}$ \\
\hline \multirow[t]{2}{*}{ Economic utility } & \multirow[t]{2}{*}{$\begin{array}{l}\text { Costs and income relative to amounts } \\
\text { transported expressed in cents per tonne-km }\end{array}$} & Sustainable returns for service providers & Reduction in cents per tonne-km (short term) \\
\hline & & Market-bearing rates for freight owners & $\begin{array}{l}\text { Dynamic management of optimum level informed } \\
\text { by investment needs }\end{array}$ \\
\hline \multirow[t]{6}{*}{ Process efficiency } & Turnaround times & \multirow[t]{6}{*}{$\begin{array}{l}\text { Indicates the efficiency of processes (increase } \\
\text { 'capacity' with the same amount of resources) }\end{array}$} & Reduced turnaround and cycle times \\
\hline & $\begin{array}{l}\text { Total cycle time (road or rail throughput time } \\
\text { from hub-to-hub) }\end{array}$ & & Increased volumes handled \\
\hline & Total volumes handled & & $\begin{array}{l}\text { Total handling, loading and standing time = } \\
\text { design time }\end{array}$ \\
\hline & Port stockpile status $\S$ & & Actual stacker-reclaimer tonnes per hour $=$ target \\
\hline & \multirow[t]{2}{*}{$\begin{array}{l}\text { Stacker-reclaimer demand availability, } \\
\text { productivity, utilisation } \S\end{array}$} & & $\begin{array}{l}\% \text { availability of stacker-reclaimer }=\text { demand } \\
\text { (allowing for maintenance) }\end{array}$ \\
\hline & & & $\begin{array}{l}\% \text { stacker/reclaimer hours utilised approaches } \\
\text { total hours available }\end{array}$ \\
\hline
\end{tabular}

$\dagger$, Relevant to bulk export corridors and export legs of multi-modal corridors; $\ddagger$, Relevant to rail sidings; $\S$, Relevant to bulk export corridors only.

service perspective and the infrastructure perspective for both sets of corridors, respectively (the few unique attributes pertaining to bulk corridors are highlighted). (This is for ease of publication. From a systems point of view, each corridor will have a separate dashboard to optimise user interface).

The initial objective is to measure the core traffic descriptors and their variance (price, time, volumes and infrastructure, refer to literature survey), as advocated by Harrison et al. (2006); Hartmann (2013); Punungwe et al. (2009) and Martner and Garcia (2015).

From a policy perspective, for the multi-modal corridors, this translates into measures to reduce the cost of freight logistics which, in South Africa, in the short to medium term, centres on modal shift to rail because of the complete absence of intermodal solutions (refer Table2). From a policy perspective, for the bulk export corridors, efficient throughput is paramount, underpinned by equitable access as well as the alignment of producer demand, rail capacity provision and port capacity provision (refer Table 3 ).

From a customer service perspective, customers are concerned with service reliability and efficiency as contracted, and at costs and cycle times that facilitate their own competitiveness (refer Table 4). This holds true for both bulk and multi-modal corridors.

Underpinning both the policy and customer perspective is the infrastructure perspective, with the aim to ensure that sufficient capacity is provided and that this capacity is both available when required and utilised optimally (refer Table 5). 
TABLE 5: Bulk export and multi-modal corridors - infrastructure perspective key performance areas.

\begin{tabular}{|c|c|c|c|}
\hline $\begin{array}{l}\text { Key performance } \\
\text { area }\end{array}$ & Metric(s) & Rationale & $\begin{array}{l}\text { Measure of } \\
\text { success }\end{array}$ \\
\hline $\begin{array}{l}\text { Asset } \\
\text { productivity }\end{array}$ & $\begin{array}{l}\text { Percentage of actual } \\
\text { usage compared with } \\
\text { designed usage per } \\
\text { hour per asset type } \\
\text { (e.g. cranes and } \\
\text { tipplers) }\end{array}$ & $\begin{array}{l}\text { Increased } \\
\text { productivity, } \\
\text { utilisation and } \\
\text { availability reduce } \\
\text { costs, improve } \\
\text { service levels and } \\
\text { optimise capital } \\
\text { investments }\end{array}$ & $\begin{array}{l}\text { Movement } \\
\text { towards } 100 \% \text { of } \\
\text { designed usage } \\
\text { (with allowance } \\
\text { for maintenance } \\
\text { and acts of nature } \\
\text { outages) }\end{array}$ \\
\hline $\begin{array}{l}\text { Capacity } \\
\text { utilisation }\end{array}$ & $\begin{array}{l}\text { Actual utilisation of } \\
\text { assets (e.g. vehicles, } \\
\text { wagons, berths, } \\
\text { tipplers) vs. total } \\
\text { available capacity }\end{array}$ & & $\begin{array}{l}\text { Movement } \\
\text { towards } 100 \% \text { of } \\
\text { available capacity } \\
\text { (with allowance } \\
\text { for maintenance } \\
\text { and acts of nature } \\
\text { outages) }\end{array}$ \\
\hline $\begin{array}{l}\text { Capacity } \\
\text { availability }\end{array}$ & $\begin{array}{l}\text { Designed corridor } \\
\text { capacity (maximum } \\
\text { vehicles and tonnes by } \\
\text { design) reduced } \\
\text { according to planned } \\
\text { outages (e.g. } \\
\text { maintenance) and } \\
\text { unplanned outages (e.g. } \\
\text { accidents) of the } \\
\text { corridor }\end{array}$ & & $\begin{array}{l}\text { Capacity } \\
\text { availability to } \\
\text { approach design } \\
\text { capacity }\end{array}$ \\
\hline
\end{tabular}

\section{Narrative of expected results and derived policy implications}

The purpose of this article is to establish the rationale for developing a CPMS and to describe the foundation framework of South Africa's CPMS. The initial population of the system is not yet completed, and results will be premature. Some overarching observations can, however, be gleaned from the initial population of the system for illustrative purposes. These examples are limited to the policy view.

\section{Corridor volumes, cost and value}

There is an important interplay between the volumes transported on corridors, the transport costs on each corridor and the value of commodities transported. The coal export corridor (Mpumalanga-Richards Bay) has the highest freight density; the Gauteng-Durban corridor is the largest corridor by freight value, whereas the Gauteng-Cape Town corridor reflects the highest costs to the economy (because of the longdistance and low rail market share). This informs policy development to enhance the logistics value added to highvalue freight (the Gauteng-Durban corridor), to reduce national logistics costs (the Gauteng-Cape Town corridor), and supports beneficiation policies in order to reduce the relative transport cost-to-value ratio of freight.

\section{Tariffs}

Road cannot be competitive on bulk corridors; the pertinent policy issue here is equitable access and sufficient capacity. For the general freight corridors, there is a direct relationship between improved rail density and a reduced road-to-rail tariff gap. This confirms the importance of improving rail density through policy, but also, in the case of the GautengCape Town corridor, that policy-facilitated modal shift of large volumes creates an opportunity for systemic change.

\section{Corridor efficiency}

The interplay between transporting the targeted commodity on its dedicated bulk corridor and releasing capacity for other commodities, such as general freight commodities on the coal corridor, can be observed. By releasing inadequate capacity for the targeted commodity, such as the case on the manganese export line a few years ago, bulk freight that should not be on road had to shift to road. This has a double negative effect, on the one hand heavily overburdening road infrastructure but, on the other hand, when rail capacity is created to meet demand and demand for bulk commodity transport on road weakens, that road overcapacity is created, leading to unsustainable tariffs in other areas.

\section{Freight flow segmentation and capacity}

Freight flow segmentation enables targeting corridors with the highest potential cost savings (the Gauteng-Cape Town corridor) and indicates where capacity should be created. A clearer view of capacity challenges also emerge by identifying freight that 'consumes' only short, but unfortunately critical, portions of a corridor, thereby negatively impacting the capacity of the full corridor.

Once the system has been populated and rolled out, a detailed analysis of the measurement perspectives will be conducted.

\section{Key strengths and challenges influencing the development of South Africa's corridor performance measurement system}

The following key situational strengths aided the development of South Africa's CPMS:

- On a macrologistics level, South Africa has the benefit of established geographically disaggregated freight flow and logistics models that combine the functionalities of primary and secondary indicators. In addition, these methodologies and applications have been peer-reviewed and refined over the past decade, and commitment for data provision from major logistics role-players, and from funding sources for modelling, has been forthcoming in the past. This is, however, a major challenge in other developing regions.

- These established models provided defined corridors for measurement purposes.

- A desire by public and private stakeholders to improve corridor efficiency not only urged by economic realities but also aided by the discourse enabled over the past decade through these established models. This translated into a willingness to collaborate in the development of an agreed measurement framework.

The following challenges emerged and require management:

- Communication and cooperation between, and continuous buy-in from project stakeholders are an enduring challenge, not in the least because of the lack of continuity in individuals in both the private and public sector. This, at minimum, requires overt project management processes and detailed project documentation.

- South Africa has a complex institutional arrangement in the freight logistics realm. The Department of Transport is responsible for developing and implementing an 
enabling legislative framework that will allow the transport industry to contribute optimally to the country's socio-economic growth ideals, whereas the Department of Public Enterprises drives profitable performance of state-owned companies such as Transnet as instruments of economic growth within this legislative framework. The existence of two controlling Ministries with different objectives is uncommon and a potential cause of policy weakness. There is, therefore, a need for better coordination between the two departments to ensure effective outcomes (TIPS 2014).

- Continuous CPMS data population and system enhancements have onerous funding requirements that need to be proactively managed by the Steercom.

\section{Conclusion}

One of the cornerstones of improved national freight logistics performance is the availability of reliable indicators to quantify the efficiency and capacity of the logistics network over the intermediate and long term, thereby enabling an evidence-based policy and investment environment. The design of South Africa's CPMS is the first step to generate such indicators in order to facilitate the systemic management of corridors as a national production factor.

The foundation framework of South Africa's freight CPMS, as described in this article, has been signed off. The alpha version testing is nearing completion (as at October 2016). The beta version of the bulk corridor CPMS is scheduled to launch towards the end of 2016 to a pre-defined set of users from key stakeholders.

The automated, timely provision of data and continuous commitment from identified stakeholders have proven to be the key challenges to be managed by the project sponsor, the Department of Public Enterprises.

The KPAs and metrics presented can serve as a platform for the development of CPMS in other regions to unlock time and resources for the establishment of the systemic and relationship integration process, which is at the core of the success of such a system.

\section{Next steps}

In the short term:

- Establish a Steering Committee with representatives from major industry associations (comprising LSPs and freight owners), state-owned infrastructure owners and operators (Transnet and SANRAL), the sponsor Department of Public Enterprises, and supporting Ministries of Trade and Industry, and Transport.

- Add directionality of freight to facilitate freight flow planning.

- Add externality cost of corridor transport to inform modal split planning and externality policies.

- Development of benchmarks and baseline indicators to evaluate performance and to trigger alerts.
In the medium term:

- The development of rules to identify and assess deviations from agreed benchmarks is required, as well as the development of accountabilities and parameters to guide the creation of response plans addressing the supply chain challenges generated by these deviations.

- Develop mechanisms to reflect total supply chain opportunity costs (recognising inter alia service reliability and speed) to inform modal shift targets.

- Define and develop combined indicators for enhanced analytical power.

In the longer term, the sourcing of truck GPS data to enhance road origin-destination modelling is a major addition to the data sources that is being investigated.

On a broader level, the role of corridors in facilitating regional economic development, inclusive growth and market access improvements, should be analysed, and the incorporation of related strategies and indicators in the CPMS investigated.

\section{Acknowledgements Competing interests}

The authors declare that they have no financial or personal relationships that may have inappropriately influenced them in writing this article.

\section{Authors' contributions}

J.H.H. contributed to methodology design, desktop research, workshop facilitation, strategic interpretation and writing. A.d.B. involved in project management, stakeholder liaison, desktop research and synthesising of workshop outputs.

\section{References}

Armstrong and Associates Inc, 2016, Global 3PL market size estimates, viewed 12 July 2016, from http://www.3plogistics.com/3pl-market-info-resources/3pl-marketinformation/global-3pl-market-size-estimates/

Arvis, J.F., Mustra, M.A., Ojala, L., Shepherd, B. \& Saslavsky, D., 2010, Connecting to compete 2010: Trade logistics in the global economy - The logistics performance index and its indicators, The International Bank for Reconstruction and index and its indicators, The
Development, Washington, DC.

Arvis, J.-F., Mustra, M.A., Panzer, J., Ojala, L. \& Naula, T., 2008, 'Chapter 1.4 Connecting to compete: Trade logistics in the global economy', in R.Z. Lawrence, J. Blanke, M.D. Hanouz \& J. Moavenzadeh (eds.), The global enabling trade report 2008, pp. 53-56, World Economic Forum, Geneva.

Brunner, H.P., 2013, What is economic corridor development and what can it achieve in Asia's Subregions?, Asian Development Bank Economics Working Paper Series, (117), viewed 13 July 2016, from https://openaccess.adb.org/ bitstream/handle/11540/2308/reiwp-117-economic-corridor-development. pdf?sequence $=1$

Chow, G., 2007, 'A total logistics cost approach to measuring collateral benefits of security and supply chain improvements at international gateways', Calgary Asia Pacific Gateway and Corridor Round Table, Calgary, 28-29th March.

Cobbold, I. \& Lawrie, G., 2002, 'Classifications of balanced scorecards based on their intended use', Presented at PMA Conference, Boston, MA, 17-19th July.

De Jong, G., Vierth, I., Tavasszy, L. \& Ben-Akiva, M., 2013, 'Recent developments in national and international freight transport models within Europe', Transportation 40, 347-371. http://dx.doi.org/10.1007/s11116-012-9422-9

Demkes, R. \& Tavasszy, L.A., 2000, 'Benchmarking infrastructure and logistics services across Europe, Asia-Pacific and North America', paper presented at IMRL 2000 Third International Meeting for research in Logistics, Trois-Rivieres, QC, 09-11 May 2000.

Dion, F. \& Skabardonis, A., 2015, San Diego I-15 demonstration Integrated Corridor Management System: PATH report on stage 3: Site demonstration and evaluation viewed 16 October 2016, from http://escholarship.org/uc/item/7f96m702 
Eisele, W.L., Tardif, L.-P., Villa, J.C., Schrank, D.L. \& Lomax, T., 2011, 'Evaluating globa freight corridor performance for Canada', Journal of Transportation of the Institute freight corridor performance for Canation Engineers 1(1), 39-57.
of Transortar

Farzaneh, R., Ramani, T., Krishnan, A. \& Zietsman, J., 2012, Performance measures for sustainable freight movement, University Transportation Centre for Mobility, Texas Transportation Institute, UTCM Project \#09-37-15, viewed 16 October 2016, from http://utcm tamu.edu/publications/final_reports/Zietsman_09-37-15.pdf

Harrison, R., Schofield, M., Loftus-Otway, L., Middleton, D. \& West, J., 2006 'Developing freight highway corridor performance measure strategies in Texas', TxDOT Project 0-5410, December, viewed 28 October 2016, from http://ctr. utexas.edu/wp-content/uploads/pubs/0_5410_1.pdf

Hartmann, O., 2013, Corridor transport observatory guidelines. Africa Transport Policy Program (SSATP), Working Paper no. 98, November 2013, The International Bank for Reconstruction and Development, viewed 28 October 2016, from https:// www.ssatp.org/sites/ssatp/files/publications/SSATPWP98-Guidelines-CorridorObservatory.pdf

Havenga, J.H., 2010, 'Logistics costs in South Africa - The case for macroeconomic measurement', South African Journal of Economics 78(4), 460-478. http://dx.doi. org/10.1111/j.1813-6982.2010.01252.

Havenga, J.H., 2013, 'The importance of disaggregated freight flow forecasts to inform transport infrastructure investments', Journal of Transport and Supply Chain Management 7(1), Art. \#106. http://dx.doi.org/10.4102/jtscm.v7i1.106

Havenga, J.H., 2015, 'Macro-logistics and externality cost trends in South Africa Underscoring the sustainability imperative', International Journal of Logistics Research and Applications 18(2), 118-139. http://dx.doi.org/10.1080/13675567. 2015.1015509

Havenga, J.H., De Bod, A., Simpson, Z.P., Viljoen, N. \& King, D., 2016, 'A Logistics Barometer for South Africa: Towards sustainable freight mobility', Journal of Transport and Supply Chain Management 10(1), a228. http://dx.doi.org/10.4102/ jtscm.v10i1.228

Havenga, J.H. \& Pienaar, W.J., 2012a, 'Quantifying freight transport volumes in developing regions: Lessons learnt from South Africa's experience during the 20th century', Economic History of Developing Regions 27(2), 87-113. http:// dx.doi.org/10.1080/20780389.2012.745666

Havenga, J.H. \& Pienaar, W.J., 2012b, 'The creation and application of a national freight flow model for South Africa', Journal of the South African Institution of Civil Engineering 54(1), 2-13.

Havenga, J.H. \& Simpson, Z., 2013, Logistics costs and efficiency. 10th Annual State of Logistics Survey for South Africa: Bold Steps Forward, viewed 16 October 2016, from http://www.csir.co.za/sol/docs/10th_SoL_Bold_Steps_Forward_web.pdf

Havenga, J.H. \& Simpson, Z., 2014, 'South Africa's freight rail reform: A demand-driven perspective', Journal of Transport and Supply Chain Management 8(1), Art. \#153, http://dx.doi.org/10.4102/jtscm.v8i1.153

Hirsch, A., 2005, Season of hope: Economic reform under Mandela and Mbeki, University of Kwazulu-Natal Press, Scotsville.

Kallas, S., 2011, White Paper on Transport: Roadmap to a single European transport area-Towards a competitive and resource-efficient transport system, DirectorateGeneral for Mobility and Transport, European Union, viewed 02 April 2016, from http://ec.europa.eu/transport/themes/strategies/doc/2011_white_paper/ white-paper-illustrated-brochure_en.pdf
Kaplan, R.S. \& Norton, D.P., 1996, Translating strategy into action: The Balanced Scorecard, President and Fellows of Harvard College, Boston, MA

Keebler, J.S. \& Durtche, D.A., 1999, Keeping score: Measuring the business value of logistics in the supply chain, Council of Logistics Management, Oak Brook, IL.

Kunaka, C. \& Carruthers, R., 2014, Trade and Transport Corridor Management Toolkit, World Bank, Washington, DC, 16 October 2016, from https://openknowledge. worldbank.org/handle/10986/18241

Levitt, T., 1960, 'Marketing Myopia', Harvard Business Review, July-August, pp. 45-56.

Liao, C.-F., 2014, Using truck GPS data for freight performance analysis in the Twin Cities metro area, Department of Civil Engineering, University of Minnesota Research Project Final Report 2014-14, viewed 16 October 2016, from http:// www.dot.state.mn.us/research/TS/2014/201414.pdf

Martner, C. \& Garcia, G., 2015, Performance measurement for intermodal corridors: A methodological approach. Logistics development strategies and performance measurement, Roundtable Report 158, International Transport Forum, viewed 15 July 2016, from http://www.itf-oecd.org/sites/default/files/docs/logisticsstrategy-performance-management.pdf

Mohr, P. \& Fourie, L., 1996, Ekonomie vir Suid-Afrikaanse studente, J.L. van Schaik Akademies, Pretoria.

Morgan, C., 2004, 'Structure, speed and salience: Performance measurement in the supply Chain', Business Process Management Journal 10(5), 522-536.

Ntamutumba, C., 2010, Study for the establishment of a permanent regional corridor development working group in PMAESA region, Funded by UN-ECA viewed 28 October 2016, from http://www1.uneca.org/Portals/atpc/ CrossArticle/1/Events_Documents/23-25Nov10Mombasa/Presentation $\% 20$ on $\% 20$ Study $\% 20$ Report.pdf

Punungwe, G., Munyaradzi, R. \& Simataa, B., 2009, 'Technical report: Study on development and establishment of a Corridor Performance Monitoring System for the Trans Kalahari Corridor', Submitted to USAID/Southern Africa, Gabarone, viewed 28 October 2016, from http://www.mcli.co.za/mcli-web/downloads/ docs/PNADU571.pdf

Samuelson, P.A. \& Nordhaus, W.D., 1989, Economics, McGraw-Hill Book Company, New York.

Sanchez-Triana, E., Afzal, J., Biller, D., Malik, S., 2013, Greening growth in Pakistan through transport sector reforms: A strategic environmental, poverty, and socia assessment, World Bank, viewed 02 April 2016, from http://elibrary.worldbank. org/doi/book/10.1596/978-0-8213-9929-3

Terreblanche, S.J., 1994, 'n Geskiedenis van opeenvolgende ekonomiese stelsels, Southern Boekuitgewers, Halfweghuis.

TIPS (Trade and Industrial Policy Strategies), 2014, Review of regulation in the Ports Sector, viewed 16 October 2016, from http://www.tips.org.za/research-archive/ trade-and-industry/economic-regulation/item/2768-review-of-regulation-in-theports-sector

Transport Canada, 2014, Gateways \& Trade Corridors - Fluidity indicator, June 2014 viewed 16 October 2016, from http://slideplayer.com/slide/10968508/

World Bank, 2016, Logistics performance index - Global rankings, viewed 12 July 2016, from http://Ipi.worldbank.org/international/global 